\title{
HOW NOT TO REGULATE AIR TRANSPORTATION
}

\author{
James A. Durham*
}

There was a time when it was quite relevant to debate whether a particular industry should be regulated by the Federal Government. In many areas of our economy that question is now moot; certainly air transportation is a segment where the decision to regulate is irrevocable. In this framework our attention is turned to such matters as the appropriate objectives and techniques of regulation. These are vital areas of inquiry in connection with the work of the Civil Aeronautics Board, and particularly with its efforts to cope with the problems of air cargo which have emerged since the recent war.

\section{Board "Regulation" of Air Cargo}

The so-called "regulation" of air cargo by the $\mathrm{CAB}$, which this writer assumes other contributors will describe extensively, need not be fully repeated here. It is sufficient for the discussion to follow to recall but a few pertinent facts.

In early 1946 there were filed with the Civil Aeronautics Board fourteen applications for certificates of public convenience and necessity by new carriers seeking to participate in air freight transportation. ${ }^{1}$ At approximately the same time seventyeight persons sought authorization to engage indirectly in the air freight business as forwarders. ${ }^{2}$ All applications were strenuously opposed by the entrenched passenger carriers, or by their trade association, the Air Transport Association of America. These latter efforts did not go in vain. It was not until May, 1947, that the freight carriers which had managed to survive were permitted to operate temporarily until final decision on their applications; ${ }^{3}$ it was not until September, I948, after most of them had been forced out of business, that forwarders were extended a similar temporary exemption; ${ }^{4}$ and it was not until July, I949, more than three years after the filing of the fourteen applications, that three of the remaining

* B.A. 1939, Ohio Wesleyan University; LL.B. 1942, M.B.A. 1948, Indiana University. Raymond Rescarch Fellow, University of Chicago Law School; formerly attorney, Civil Aeronautics Board. Contributor to Iegal and other periodicals.

${ }^{1}$ Air Freight Certificate Case, Docket 810, Examiner's report, at $2 \mathrm{I}$ et seq. One of the applicants was Capital Airlines, a passenger carrier whose routes are limited to the eastern part of the United States.

${ }^{3}$ Air Freight Forwarder Case, Docket 681, Examiner's report, at $\mathrm{x}$. This number included the Railway Express Agency, which proposed to handle both freight and express over the routes of both passenger and freight carriers. The Agency has been permitted to move express only over the routes of the passenger carriers, a status which has been reaffirmed by the Board's decision in the Air Freight Certificate Case, Order Serial No. E-3085, July 29, I949.

${ }^{3} \mathrm{CAB}$ Economic Regulations, Section 292.5, Order Serial No. 389, May 5, 1947.

* Air Freight Forwarder Case, Order Serial No. E-1968, September 8, x948. 
cargo carriers were awarded certificates of public convenience and necessity, though on a temporary five-year basis. 5

While the Board's right hand finally gave this measure of recognition to the new freight industry, its left hand meted out indirect obstacles and repudiations one after another. For example, by July, I949, the applications of most of the other direct and indirect freight carriers had become academic by reason of their financial difficulties. In great measure these flowed from a rate war begun in June, 1946, and still continuing with but little Board interference. Initially the rates took the form of below-cost contract rates, yielding in some instances as low as eleven cents per ton mile, ${ }^{6}$ but once the independent freight carriers were permitted to operate under temporary exemption from the certification requirement the entrenched carriers concentrated upon equally low rates for scheduled operations. ${ }^{7}$ Finally, some of the tariff filings were suspended by the Board, ${ }^{8}$ and an investigation ensued which terminated in an unusual minimum rate formula yielding revenues below the costs of even the most efficient carriers. ${ }^{9}$ Almost immediately a stampede started to bring the rates of most commodities down to the minimum, ${ }^{10}$ though the Board had solemnly warned the industry that it would take "action" if this occurred.11 $U_{p}$ to this date the Board has done little to stop this defiance, other than to order an "investigation" which may take years to complete," and consequently the rate war continues.

In fact, in some cases the Board has even made defiance of its minimum rate order profitable to the entrenched carriers. This arises by virtue of the fact that the mail subsidy awarded individual carriers under Section $406(\mathrm{~b})$ of the Act is determined according to the over-all "break-even" need, plus a return on "recognized" over-all investment. ${ }^{13}$ In this setting losses experienced from freight rate

5Air Freight Certificate Case, Order Serial No. E-3085, July 29, I949. In the same procecding a certificate was granted to Airnews, Inc., a wholly owned subsidiary of the Express Publishing Company of San Antonio, authorizing this carrier to transport newspapers published by its parent and other property to and from small cities in the Rio Grande Valley.

${ }^{\circ}$ N. Y. Times, June 12, 1946, p. 25, col. 5; Aviation Daily, June 6, 1946; Air Freight Rate Investigation, Docket 1705 , transcript of hearing at $6 \mathrm{x}-63$. It is interesting to compare these with the 70 cent rates prevailing in 1944. See Hummon, Research Pays Off in Air Freight, U. S. Dep'T or AguculTURe, Marketing Activities 3 (Sept. I949).

"Air Freight Forwarder Case, transcript of hearing at W-2589; Air Freight Rate Investigation, transcript of hearing at 65,227 .

${ }^{8}$ Suspension and Investigation, Air Freight Tariffs, $8 \mathrm{CAB}$ 62x (1947).

- Order Serial Nos. E-1415 and E-1639, April 2I, 1948, and June 2, 1948. The formula cstab. lished minimum rates of 16 cents per ton-mile on the first 1,000 ton-miles of any shipment, and 13 cents per ton-mile for ton-miles in excess of $\mathrm{I}, 000$ ton-miles in any shipment.

${ }^{10}$ The average rate received by domestic carriers was but 12.68 cents per ton-mile in 1948 . Dissenting opinion of Member Jones in Air Freight Certificate Case, Order Serial No. E-3085, July 29, 1949. Tariff filings in 1949 would have little impact upon this average.

${ }^{11}$ Order Serial Nos. E-1415 and E-1639, April 25, 1948, and June 2, 1948.

${ }^{12}$ Class Rate Investigation, Docket 3665, Order Serial No. E-2486, February 21, 1949. Upon the complaint of two of the all-freight carriers the Board did suspend certain tariffs designed to extend the lowest possible rates under the minimum rate order to the whole country. Order Serial No. E-2104, October 18,1948 .

${ }^{13}$ Of course, a small amount of total mail pay awards would be necessary in any event to cover the cost of carrying the mails. But as Senator Johnson of Colorado, Chairman of the United States Senatc 
cutting are for practical purposes treated as another expense of doing business. In most of the mail subsidy awards made since the beginning of the rate war in June, 1946, the Board has simply ignored this problem. For example, in the Big Four mail rate proceeding, which is by far the most important of these cases by reason of the carriers involved, ${ }^{14}$ the Board's tentative opinions refer to the over-all need of this group of carriers without reference to the fact that three of them have been engaged in destructive freight rate cutting for over three years. ${ }^{15}$ In five instances the relationship between mail pay and freight losses has been faced by the Board, and in three of these the Board has been willing to let the carriers recoup their freight losses; ${ }^{16}$ in a fourth instance freight losses have been temporarily disallowed by an approach which suggests they may subsequently be allowed; ${ }^{17}$ and in the fifth instance recoupment has been barred by an approach which shies away from the issue. ${ }^{18}$ These actions were in direct contrast to the pious verbiage of a previous Board opinion that reporting procedures would be employed to prevent the use of mail subsidy to finance losses incurred in a rate war. ${ }^{10}$

Moreover, up until recently the Board has seized upon the flimsiest of procedural excuses to prevent the nonsubsidized freight carriers from getting a clear-cut decision on the mail-subsidy-freight-rate issue. Thus in the Air Freight Rate Investigation, the Board indicated that this matter should be decided in mail rate proceedings, ${ }^{20}$ but for several months thereafter when representatives of the freight industry sought to present their case in mail proceedings they were either barred or ignored, ${ }^{21}$ in

Interstate and Foreign Commerce Committee, pointed out in an address before the Kansas City Chamber of Commerce on July 15, 1949, "Clearly the CAB is underwriting the airline commercial losses with mail pay. No one knows how much of these payments are subsidy and how much is compensatory." The Senator expressed the view that "to $\mathrm{mix}$ mail pay with subsidy is a sloppy and wasteful way to do business." The formulation of mail rate policy from 1938 through mid-1946 is described extensively in Burt and Highsaw, Regulation of Rates in Air Transportation, 7 LA. L. REv. 378, 393 (1946-1947).

is In the industry the "Big Four" identifies American Airlines, Inc., Eastern Air Lines, Inc., Transcontinental \& Western Air, Inc., and United Air Lines, Inc. These carriers transported approximately 81 per cent of domestic air mail in 1948 , and received approximately 50 per cent of the mail pay awarded to domestic carriers. Hearings before Senate Committee on Interstate and Foreign Commerce, 8Ist Cong., Ist Sess. 489, Appendix I (1949), and CAB recurrent reports.

${ }^{26}$ Order Serial Nos. E-1351 to 1355, March 29, I948; Order Serial Nos. E-1517 to 1521, May 7, 1948; Order Scrial No. E-2484, February 2I, I949.

${ }^{10}$ Braniff Airways, Inc., Mail Rates, Order Serial No. E-1931, September 2, 1948; Delta Air Lines, Inc., Mail Rates, Order Serial No. E-1959, September 7, 1948; Capital Air Lines, Inc., Mail Rates, Order Scrial No. E-2675, April I, I949. In the latter proceeding, the Board tentatively has disallowed losses arising out of the use of $\mathrm{C}-47$ equipment, but has indicated its willingness otherwise to make up in mail pay for freight losses providing the carrier abides by the below-cost minimum rates established by the Board. Thus if a carrier receives I 6 cents per ton-mile, for transporting freight, which operation cost the carrier $2 \mathrm{I}$ cents per ton-mile, the Board will pay 5 cents per ton-mile to offset this loss from freight.

${ }^{17}$ Pan American-Grace Airways, Inc., Mail Rates, Order Serial No. E-2710, April 12, 1949. In this tentative opinion the Board announced that cargo losses would not necessarily be underwritten, depending upon the circumstances in "each case." Before a final opinion is issued the carrier is in a position to demonstrate that this is a proper case for the use of mail subsidy to underwrite cargo losses.

${ }^{23}$ Pan American Airways, Inc., Transatlantic Services, Mail Rates, Order Serial No. E-2728, April 19, 1949.

${ }^{10}$ Motions of Air Freight Forwarder Association, $8 \mathrm{CAB} 469,474$ (1948).

${ }^{20}$ Order Serial No. E-1639, June 2, 1948.

${ }^{21}$ Order Serial Nos. E-2035 and 2036, September 30, 1948; E-2086, October I4, I948; E-2189, 
spite of quite a liberal policy on interventions in cases where there were important issues. ${ }^{22}$ Finally, in recent months the Board has granted "limited intervention" to freight carriers in two mail cases where there is serious question that subsidy is financing freight operations. ${ }^{23}$

The lack of reporting procedures that will permit a reasonably accurate comparison of the freight costs and revenues of the dominant passenger-mail carriers is an amazing spectacle in this day of penetrating accountancy. By and large the Board has simply ignored demands for the establishment of such procedures, as in the Air Freight Rate Investigation where the request was so obviously relevant. ${ }^{2-4}$ Recently legislation has been introduced which, among other things, would compel separate reporting for air cargo; ${ }^{25}$ this has been met with a Board-backed proposal that Congress pass a resolution authorizing an exhaustive $C A B$ mail pay study which might require the Board to reallocate overhead costs among the various classes of services rendered. ${ }^{26}$ It must be obvious that the time taken to get such a resolution through the Congress, the period for the study, and the time necessary to put reporting procedures into effect would give the entrenched carriers abundant opportunity to eliminate the remaining all-freight direct and indirect carriers through continued use of mail pay to finance low freight rates. This approach on the part of the Board, coupled with its inaction on this subject during the whole period of air freight development, suggests the conclusion that the relationship between the Board and the principal passenger-mail carriers borders on benevolent cooperation.

Nor has the Board sought a favorable climate for the implementation of its decisions. After the freight carriers temporarily were exempted from the certification requirement, they sought to develop new traffic from new points, and in accordance with the economic regulation under which they were operating sought Board permission to use such additional points. These requests were coldly received, $^{27}$ yet at least one Board member, ${ }^{28}$ to say nothing of the entrenched car-

November 12,. 1948; E-2296, Decembcr. 15, 1948; and E-2297, December 16 , 1948. In these cases where the Board has refused to permit intervention, representatives of the freight industry have becn permitted to state their position at a pro forma hearing before an Examiner subsequent to the issuance of tentative mail rate opinions, as in the Braniff and Delta cases, note 16 supra. Since the Examincr's report in mail rate proceedings does not discuss the merits of the case, however, whatever statements of position that have been made at such pro forma hearings would appear to be of no significance in the formulation of the Board's final decision.

${ }^{22}$ In the Air Freight Certificate Case, for example, some 65 persons or groups were permitted to intervene formally, and in addition appearances were entered for some 27 others.

${ }^{23}$ Order Serial Nos. E-2717, April I4, 1949 (Members Jones and Adams dissenting), and E-2733, April 19, 1949.

${ }^{24}$ See particularly brief of public counsel in Air Freight Rate Investigation, at 66, 69.

${ }^{25}$ S. I43r, 8ist Cong., Ist Sess. (I949). Unfortunately, this bill and a more recently offered sub. stitute (S. 2437) contain formulae for the determination of mail pay which would give the principal mail carriers alleged "compensatory rates" which in some instances would exceed the presently subsidized rates.

${ }^{20}$ S. J. Res. 92, 8rst Cong., Ist Sess. (1949).

s7 Administration of the exemption order was delegated to the staff. Sce the briefs of The Flying Tiger Line and Slick Airways, Inc., in Air Freight Certificate Case, discussing this matter.

${ }^{28}$ For example, see the dissenting opinion of Member Jones in the Air Freight Certificate Case, Order Serial No. E-3085, July 29, I949, at 24-5. 
riers, ${ }^{20}$ continued to demand why the freight carriers were not serving a larger number of points. Likewise, after finally granting the forwarders permission to do business after two earlier rejections, ${ }^{30}$ in a routine order the Board almost immediately whittled away the significance of its Forwarder decision by placing the entrenched carriers in the forwarder business. ${ }^{31}$ Moreover, after indicating that the freight carriers would be permitted to handle express traffic, ${ }^{32}$ this rich source of revenue finally was allotted to the passenger carriers exclusively. ${ }^{33}$

The Board even gave the established airlines protection from the antitrust provision of the Act. ${ }^{34}$ In June, 1946 , when the rate war began, the entrenched grandfather group determined to employ rate conferences and a consolidated freight tariff, and sought Board approval of this approach. The Board initially refused either to approve or disapprove this agreement, ${ }^{35}$ but within two weeks after the filing of motions requesting $e x$ parte approval the Board concluded the matter by approving the agreement $!^{36}$ This action was taken with full realization-recognized in different ways in both majority and dissenting opinions-that the agreement could be employed to cut down the new competition from the freight carriers. True enough, as a technical matter this agreement was approved only temporarily, but of course during the period when freight carriers were seeking certificates the device could be employed by the established carriers to destroy their competitors. In this context the real meaning of temporary approval was tantamount to final approval, in as much as elementary knowledge of antitrust proceedings leaves no room for doubt that a final decision would take considerable time and staff. As a matter of fact, the Board's investigation of this particular agreement has not yet reached the hearing stage after nearly three years. ${ }^{37}$

Perhaps the most unfortunate thing about the foregoing type of public conduct was that it occurred at a crucial time in the development of air transportation. During the depression years, when government first moved to control the air transportation industry, the emphasis was on using the mail subsidy device to give it aid and comfort. The war prosperity substantially reduced the necessity for this

${ }^{29}$ See particularly the briefs of American Airlines, Inc., and United Air Lines, Inc., in the Atr Freight Certificate Case.

${ }^{30}$ Order Serial Nos. E-1343, April 2, 1948 (Member Lee dissenting); E-r445, April 26, 1948 (Member Lee dissenting); and E-1968, September 8, r948 (Member Jones dissenting).

${ }^{31}$ Order Serial No. E-2023, September 28, 1948.

${ }^{32}$ Air Freight Forwarder Case, Order Serial No. E-1968, September 8, 1948.

${ }^{33}$ Air Freight Certificate Case, Order Serial No. E-3085, July 29, 1949.

${ }^{34}$ Under Section $4 \mathrm{I} 4$ of the Civil Aeronautics Act the antitrust laws are applicable in the absence of affirmative action by the Board under Sections 408,409 , and 412 of the Act. 52 Stat. I004 (1938), 49 U. S. C. $\$ 494$ (1946).

35 Air Freight Tariff Agreement Investigation, Docket 2719, Order Serial No. E-179, December 12, 1946.

${ }^{33}$ Order Serial No. E-339, February 24, 1947 (Member Lee dissenting). For some reason the Board did not see fit to publish in CAB Opinions this very significant step. In Sweeney, Policy Formation by the Civil Aeronattics Board, I6 J. Arr LAw \& Com. 127, 157 (1949), the failure of the Board to publish significant policy decisions and opinions when not connected with a final determination is criticized vigorously.

${ }^{37}$ The investigation was begun in December 1946; hearings are scheduled to begin in October I949. 
type of aid, but once the demand for luxury travel tapered off and vendors of air coach and air freight service gave challenge, the thinking of the established industry $^{38}$ and the Board fell back upon the old mail subsidy solution. The apparent conclusion that no certificated carrier should be forced to endure bankruptcy ${ }^{30}$ led to the further conclusion that others should be discouraged from participating in the further development of aviation, that the Board would employ its procedures and taxpayers' monies to recoup the freight and other losses of such carriers, and that the salvation of the early-born carriers, irrespective of the character of their management, was the prime objective of Board policy.

It would not be accurate to say that these were conscious Board objectives, or even conscious staff objectives, though unquestionably many of the individuals participating in the "regulatory" process, sometimes happily and sometimes unhappily, were aware of the march of events. To some extent new economic factors were sufficiently strong to override the usual attitudes, but only after enterprise outdistanced and made the old solutions appear outworn and untenable. The caution and inconsistent pattern of the Board's case-by-case approach is better understood when the indecisive attitude of individual Board members is set out case-by-case. Member Josh Lee, once regarded as an "expansionist" and friend of the new freight carriers, ${ }^{40}$ (I) voted consistently to permit the forwarders to participate in air transportation, the first time as a minority of one, ${ }^{41}$ (2) dissented vigorously when the Board exempted the established carriers from the Act's antitrust provision during the rate war, ${ }^{42}$ and (3) agreed to allow the freight lines to challenge the Board's mail pay policy with respect to freight. ${ }^{43}$ Yet this same Mr. Lee (4) dissented when the Board by a 3-2 vote awarded temporary certificates to three of the freight carriers. ${ }^{44}$ The record of Vice-Chairman Ryan, once regarded as a "conservative" by spokesmen for the well-established carriers, ${ }^{45}$ is equally anomalous, though almost the opposite. He (I) originally voted with the majority to prevent the entry of forwarders, ${ }^{40}$ and (2) was in favor of the antitrust exemption for the established carriers. ${ }^{\mathbf{4 7}}$ Yet it was this same Member (3) who finally voted with the majority to permit forwarders to operate temporarily without certificates after disagreeing two previous times, ${ }^{48}$ (4) who finally agreed to letting the freight carriers challenge the use of mail pay to finance freight losses, ${ }^{49}$ and (5) who agreed that three of the freight carriers should

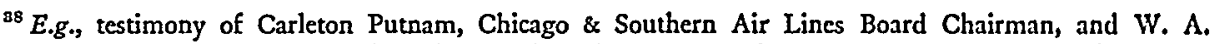
Patterson, United Air Lines President, in Hearings before Committee on Interstate and Foreign Commerce on S. Res. 50, 81st Cong., Ist Sess., 452-454, 670-672 (1949).

${ }^{30}$ Chairman O'Connell has raised the question whether the bankruptcy process would not have ecrtain advantages for air transportation. See Air Mail Pay Under the Civil Acronautics Act, an address by Chairman O'Connell before the Association of the Bar of the City of New York on March 23, 1949.

${ }^{10}$ Aviation Week, May 3, r948, p. 43.

${ }^{41}$ Order Serial Nos. E-I343, April 2, I948; E-1445, April 26, 1948; and E-1968, September 8, 1948.

42 Order Serial No. E-339, February 24, 1947. $\quad{ }^{18}$ Order Serial No. E-2717, April 14, 1949.

"Order Serial No. E-3085, July 29, I949. "See note 40 stipra.

${ }^{10}$ Order Serial Nos. E-1343, April 2, 1948, and E-1445, April 26, 1948.

${ }^{47}$ Order Serial No. E-339, February 24, ז947. - ${ }^{48}$ Order Serial No. E-1968, September 8, 1948.

${ }^{40}$ Order Serial No. E-2717, April 14, 1949.
} 
be granted temporary certificates. ${ }^{50}$ His agreement to certificate these carriers and to permit their intervention in mail pay cases came only after the former decision was postponed in the fall of $1948,{ }^{51}$ and after his reappointment in early 1949 to a full six-year term. Member Adams, whose recent appointment was well regarded among spokesmen for certificated carriers ${ }^{52}$ had (I) taken the position that freight carriers should be denied a hearing on mail pay, ${ }^{53}$ yet at the same time (2) agreed to awarding temporary certificates to three of the freight carriers. ${ }^{54}$ Prior to his appointment to the Board, Member Adams was Director of the Board's Economic Bureau, which is one of the two most influential positions on the staff. In that capacity he undoubtedly participated in formulating Board policy with respect to several of the aforementioned subjects, ${ }^{55}$ but there is no public record of his previous thinking.

Greater consistency is apparent from the records of Chairman O'Connell and Member Jones, though the conclusions they reached with respect to the aforementioned issues were diametrically opposed. The Chairman favored entry of forwarders into the business, ${ }^{56}$ believed it appropriate to give the freight carriers a hearing on the troublesome mail subsidy question, ${ }^{57}$ and favored certificates for the freight carriers. ${ }^{58}$ In very forceful opinions of dissent, Member Jones reached the opposite conclusions in each instance. Neither were members of the Board when the other crucial questions were decided. O'Connell and Jones did agree upon the establishment of a minimum freight rate ${ }^{59}$ and upon the backdoor entry of the direct carriers into the forwarding business, ${ }^{60}$ as did both Members Lee and Ryan and as did Member Adams in the latter instance. However, these unanimous votes are difficult to evaluate. That the Board should interfere with a crippling rate war seems an obvious necessity, whether the step was to keep the entrenched carriers from driving their new competitors to the wall or whether it was to prevent the dissipation of the assets of the certificated group. Because the minimum rate was established at a below-cost level, and in view of the Board's willingness to use mail subsidy to make up for freight losses, the minimum rate has had but slight impact upon either objective. The unanimous decision to let direct carriers in the forwarding business could have been the result of general Board and staff agreement that the forwarder decision made desirable mollification of the entrenched carriers; ${ }^{\text {BI }}$ it may have come

${ }^{50}$ Order Serial No. E-3085, July 29, 1949.

${ }^{61}$ Order Serial Nos. E-2ro8 and E-2109, October 20, 1948.

${ }^{62}$ See note 40 supra; American Aviation, March 15, I948, p. II.

${ }^{63}$ Order Serial No. E-2717, April 14, x949.

t* Order Serial No. E-3085, July 29, 1949.

${ }^{6 \pi}$ For a discussion of the influence of staff upon Board policy, see Sweeney, note 36 supra.

${ }^{60}$ Order Serial No. E-1 968 , September 8, 1948.

${ }^{67}$ Order Serial No. E-2717, April 14, 1949.

${ }^{18}$ Order Serial No. E-3085, July 29, 1949 .

${ }^{50}$ Order Serial Nos. E-1415, April 21, 1948, and E-1639, June 2, 1948.

${ }^{\circ 0}$ Order Serial No. E-2023, September 28, 1948.

${ }^{01}$ The decision of September 8, 1948 in the Air Freight Forwarder Case was appealed by all of the entrenched carriers but one. Sec American Airlines et al. v. Civil Aeronautics Board, Docket No. 9739, U. S. Court of Appeals, $7^{\text {th }}$ Circuit. 
from a desire to carry water on both shoulders; it may have stemmed from the feeling that the matter was unimportant; there was a feeling that fairness required the Board to permit the direct carriers to engage in forwarding on equal terms with the newcomers engaged only in forwarding. If the latter was the case, the Board would appear to have been unusually naive since, in the absence of minimum forwarding charges exceeding the cost of this function (and no attempt has been made to measure this cost), the subsidized mail carriers have no difficulty in absorbing the losses necessary to drive the forwarders to the wall. Unfortunately, the failure of the Board to issue an opinion in this matter postpones a statement of its position until after the current investigation, ${ }^{62}$ which again may take considerable time.

As might be expected, the Board's record on air cargo is symptomatic of its over-all effort. The inconsistencies of the Board's ad hoc decisions involving route extensions have been criticized; ${ }^{63}$ and its recent vacillations on mail subsidy have even evoked caustic comment in a dissenting opinion by Justice Jackson. ${ }^{04}$ The beneficiaries of Board decisions and $\mathrm{CAB}$ counsel in most instances can give long "explanations" of the Board's public acts and utterances, but these are sometimes difficult to comprehend. Perhaps these "explanations" can be better fathomed in the light of an examination of the $C A B$ universe, and the relations between its three components - the Board, its staff, and the industry.

Although the official reports of the Board and the usual expositions of its work politely ignore it, the relationships between the staff and the Board (and individual Board members), between the Board and the industry, and between the staff and the industry vitally affect Board policies and decisions. At first blush this relationship would appear little different from some of the other regulatory agencies, ${ }^{05}$ but in the case of aviation the additional factor that the agency is supporting the industry must be added. Board members are frequently on the friendliest of terms with counsel or management of individual carriers. In many instances this starts from a genuine interest in the problems of the particular carrier; in others it stems from the fact that counsel formerly was an employee of the Board; and in some instances Board members feel it discreet to keep these contacts warm lest, like former Chairman Landis, they find themselves politically unavailable for reappointment. But irrespective of the genesis of these relationships, they obviously do not throw sand in the machinery that grinds out mail subsidies and route extensions on a convenient case-by-case basis.

As problems become more complex, Board members have increased their reliance

"2 Order Serial No. E-2023, September 28, 1948.

-3 Westwood, Choice of the Air Carrier for New Air Transport Routes, 16 Geo. Wash. L. Rev. I, 159 (1947-48); Sweeney, note 36 supra.

o4 Transcontinental \& Western Air, Inc. v. Civil Aeronautics Board, 336 U. S. 601, 608 (1949).

${ }^{\circ 6}$ Even the ordinary relationships between an agency and an industry vitally affect regulation. E.g., Marquis Childs, Washington Post, April 7, I949, p. Ir, col. 3, discussing the Federal Power Commission; cditorial, Washington Post, April 22, 1949, p. 24, col. 3, discussing the Maritime Commission; Senator Johnson of Colorado, 95 Cong. Rec. 4869 (r949), discussing the Federal Communications Commission. For a discussion of this matter covering an earlier period, see E. Pendeton Herning, Public Administration and the Public Interest (1936). 
upon staff advice-a proposition repeatedly emphasized by the $C A B$ survey officer attached to the Hoover Commission on governmental reorganization. ${ }^{66}$ This raises the question of staff attitudes, a matter which realistic airline counsel have not overlooked. Fortunately for the latter, many of the most influential members of the staff have been with the Board since its earliest days, when mail pay and grandfather certificates were the primary matters of concern, and a few of them were doing similar tasks for other agencies before the establishment of the Civil Aeronautics Board. Because of a strong promotion-from-within personnel policy, and because of internal operating procedures which with few exceptions limit access to Board members to highly placed persons on the staff, such persons are now in a position to express their very sincere thoughts that it is wisest to use "caution" in the "regulatory" process, and that the Government has sunk so much subsidy into a given carrier that this "investment" should be protected by further subsidy, or by additional route extensions, or by the extinction of new competitors. After all, Board members who think otherwise will come and go, but the entrenched carriers are in the picture to stay. It takes no more than this to suggest to most new employees that their future can be best protected by giving serious weight to the suggestions made to the staff by representatives of the dominant carriers; after all, most men are sufficiently ambitious to desire promotion within the civil service and/or the proffer of airline employment at an even greater stipend. This is not to suggest or imply that staff people are either dishonest or insincere; it simply means that their conclusions are conditioned by the attitudes of their superiors and that most staff personnel, high and low, are conditioned-usually subconsciously-by the attitudes of airline counsel and management and by the process of pulling one carrier after another out of economic difficulties.

Much has been written and said about the need for specialized counsel in prosecuting claims before government agencies. The necessity for specialized counsel is difficult to generalize about, but its superior effectiveness in dealing wtih the $C A B$ cannot be overstated. It is not that specialized counsel is better prepared to file motions, write briefs, and argue cases before the Board; the real value of specialized counsel to an airline is counsel's knowledge of the various biases and ambitions of Board and particularly staff members, of the complex human relationships that exist among staff personnel, and of the tendency of certain division heads to make commitments on their own without reference to action taken in other parts of the agency. On different matters, different Board and staff members are approached; if possible, an attempt is made to get bureau or division head $A$ committed where it can be anticipated that bureau or division head $B$ will object, thus placing $A$ in a position where he will "lose face" if his commitment is overruled. Likewise, it is necessary to know which of the staff are sufficiently influential to be worth cultivating. Such intimate knowledge is a large part of the stock-in-trade of specialized aviation coun-

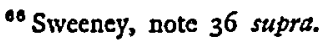


sel, ${ }^{67}$ some of whom have greater influence on specific Board decisions than do the Board's own counsel.

This suggests the psychological setting in which "regulation" and "development" of air transportation is approached. Except for the obvious public interest in having more aviation, the attitude that the agency had a job of regulating to be done in the public interest-in contract to carrier interest-never gained much of a foothold at the Civil Aeronautics Board. In this context "regulation" is much more akin to "playing the angles," and the statutory directive to "promote" and "develop" the industry comes down to rationalizing the amount of mail pay and route extensions desired by individual carriers.

II

\section{Planning Air Transportation}

Solutions to concrete problems of governmental administration do not come easily, and air transportation is by no means an exception. However, by this time it must be clear that the problems this industry presents require the formulation and development of a comprehensive master plan for all air transport. The mere redrawing of the route structure map, which $\mathrm{CAB}$ has often threatened to "suggest" to the industry but has yet to $\mathrm{do}^{68}$ is only one ingredient of the planning here proposed. In addition, questions of the function and use of mail pay, and the place of freight carriers, forwarders, air coach service, and super-luxury service, all need to be rationalized and placed in their proper perspective. As has been elsewhere indicated, there is abundant statutory authority for such an approach to air transport regulation; ${ }^{69}$ in fact, the Act practically directs such a course, since there seems no possible rational way to use broad affirmative powers in "developing, promoting, and encouraging" the industry by the case-by-case approach. It is this latter approach, which according to some Board members protects the Board from "political pressures," ${ }^{\text {"70 }}$ which makes it so convenient to decide one subsidy or route case without reference to any other, and which makes it so convenient to hand out valuable considerations first to one contestant and then to another, depending upon hunch, relationships between Board and staff and the individual carrier, and other subjective factors.

${ }^{a 7}$ There will be considerable disagreement with Marquis Childs' concluding paragraph in a column dealing with the recent " 5 per cent" Senate investigation: "Everyone who knows Washington at close range knows that the 5 -percenters who have come into this inquiry are for the most part the little fellows. The big operators are the lawyers-out of both the Old Deal and the Ncw Deal-who rarely go into a courtroom. Their specialty is influence and knowing the right people and they make millions from it. An investigation that really dug into this phase of the influence industry would hit pay dirt." Washington Post, September I, 1949, p. 9, col. 4.

${ }^{68} \mathrm{~A}$ report by the $\mathrm{CAB}$ on revision of route structures was originally promised in February 1949, and subsequently in July 1949. Sweeney, note 36 supra, at 152. This report has not yet been issued, and the Board has not announced a new date for its publication. The route structure matter is discussed in Business Week, October 9, 1948, pp. 19-20.

${ }^{60}$ Durham and Feldstein, Regulation as a Tool in the Development of the Air Freight Indiustry, 34 VA. L. Rev. 769, 791 (1948).

${ }^{70}$ Sweeney, note 36 stupra at 147 . 
But how do we go about planning the future of air transportation, in view of all the difficulties of procedure and relationship that are involved? How is it possible for the Board and its staff to approach their tasks in a psychological and mental framework that is foreign to cooperating, negotiating, or compromising with the group the agency is supposed to be regulating?

At the outset it is necessary to build a new relationship between the Board and the staff. The loyalties of the staff must not be divided among different Board members, the islands of independent authority among certain division heads need elimination, and the staff needs to be protected from the "suggestions" of some of the more effective airline counsel. The most practicable and effective way to bring this about is to place the staff directly under the Board Chairman. In the case of the Civil Aeronautics Board, the Chairman is designated by the President, and consequently persons of greater public stature have been attracted to the Chairmanship than is the case of agencies where the chairmanship rotates. ${ }^{71}$ But this reorganization need not preclude other Board Members from urging and relying upon the staff for alternative solutions to problems of air transportation. Staff presentations to Board Members need not be in terms of a single solution, which has been more or less the tendency of the CAB, but in so far as a comprehensive master plan will permit alternative solutions should be offered. The Hoover Commission on Reorganization of the Executive Branch has recommended that all the independent regulatory agencies place their staffs under their chairmen, ${ }^{72}$ a suggestion which already has been followed in the case of the Maritime Commission. ${ }^{73}$ In the case of the $C A B$, the present and historical relations between Board members probably would require that internal reorganization of this character be initiated by the White House.

Less opportunistic relationships between Board and staff also are dependent upon selections to both groups of persons of broad perspective, creative imagination, and unselfish devotion to the public service. The stars in our firmament of government administration are largely a history of men and not organization charts. Of course, the quality of appointments to the Board itself should be the President's concern, ${ }^{74}$ although greater public scrutiny of these appointments, as exists in the case of Chairmanship appointments, might well lessen the effectiveness of suggestions made by the carriers. Quite apart from this, however, were the staff to be directly re-

${ }^{71}$ The same has been true in the case of the Securities and Exchange Commission, the Federal Reserve Board, and the Federal Communications Commission, for example; and, now that the Chairman of the Maritime Commission is designated by the President, at the latter agency as well. See editorial, Washington Post, April 22, 1949, p. 24, col. 3, and cf. Letter to the Editor from George Killion, President, American President Lines, Washington Post, May 6, 1949, p. 24, col. 5 .

72 a Report to the Congress on Regulatory Commissions by the Commission on Organization of the Executive Branch of the Government 5-6 (March 1949).

${ }^{73}$ The relation of the Chairman to the staff is set forth in $U$. S. Maritime Commission, Organization and Functions, I4 Fed. Reg. 5350, $\$ \$ 5,6$ (August 27, I949).

7 The Hoover Commission Report on Regulatory Commissions, note 72 stpra, makes the following criticism of appointments to these agencies: "b. Appointments to membership on these commissions are sometimes below desirable standards because of the inadequate salaries offered, or the failure of the Execttive to appreciate the importance of the positions." Id. at 3. (Italies supplied.) 
sponsible to the Chairmian, the selection of higher-placed staff officers could turn more on the ability and contribution of the candidate and less upon such matters as seniority and popularity with the industry and Board members.

In this setting the agency should be in a better position to make full use of the techniques of planning, of accounting, of engineering, of statistics, of budgeting, and of administrative standards. The Board has authority to compel uniform accounting under Section 407 (d) of the Act; however, it permits carriers to employ any system of accounts desired in their own operations, providing expenses are uniformly reported. In actual practice, expenses reported by individual carriers often are not comparable because of a variance of the items comprising a particular uniform account. $^{75}$ The Board appears not to have taken seriously the need for objective, efficiency-engineering studies, such as time and motion studies, although their use is obvious in the case of cargo and mail handling. It may be that the reluctance to determine the cost of carrying the mail has some relation to this attitude. As a matter of fact, there are no really adequate objective data extant that point to the cost of performing any service. The possibility of employing statistics as a control device does not seem to be recognized.

It is in the failure of the agency to develop administrative standards, which would implement and supplement statutory standards, that the record of the Board's legal staff appears so inadequate. The legislative history of the standards of the Civil Aeronautics Act-so relevant to the formulation of adequate administrative standards-does not appear to be reflected in CAB decisions. Section 2 of the Act, setting forth objectives which in effect direct the Board to employ regulation as a means to developing, promoting, and encouraging aviation, by virtue of their indiscriminate use has no real meaning or content. They are recited glibly by the applicant who wants something from the Board, and are subsequently recited back by the Board after the decision to play Santa Claus has been made. The Board and staff do purport to give effect to the requirements of Section $40 \mathrm{r}(\mathrm{d})$ that a carrier be "fit, willing; and able" before issuing a certificate of public convenience and necessity, although in nearly all cases the three standards are considered but one. $^{70}$ But what meaning is ascribed to these very significant legislative standards? This writer is convinced that while in many cases a sincere attempt is made to apply the standards fairly, to one examiner they mean one thing, to another something else, to different Board members still something different. Similarly, the requirement of Section 406(b) that carriers maintain "honest, economical, and efficient management" is repeatedly called into play in determining mail subsidy awards, but again in application the meaning given these standards varies. There are other statutory standards which have received inadequate administrative attention, but these are illustrative.

"Is In numerous mail rate proceedings the CAB's staff makes "adjustments" in carrier figures to make data comparable. Such adjustments rarely appcar in formal opinions issued by the Board.

"For example, sce the opinion of the Board in the Air Freight Certificate Care, Order Serial No. E-3085, July 29, 1949. Cf. the West Coast Case, $6 \mathrm{CAB} 96 \mathrm{r}$ (1946), supplemental opinion on reconsideration, Order Serial No. E-555, May 19, 1947, and the Hawaiian Intratcritorial Case, Order Serial No. E-2496, November 29, 1948. 
The aforementioned statutory standards lend themselves admirably to the formulation of concrete administrative standards that are relevant to the regulation of air transportation. Each of the words "fit, willing, and able" and "honest, economical, and efficient" can be given special significance. In the matter of awarding certificates of public convenience and necessity, it would appear that the legislative standard "willing" carries with it much more than the idea that a New YorkChicago carrier simply wants a route extension to Milwaukee, as an example. If the carrier's request for the extension stems from a desire to prevent another carrier from being certificated, which is so often the case, there is an obvious lack of good faith which would appear to be in conflict with a professed willingness to give the best possible service between Chicago and Milwaukee. A carrier's willingness to gain an extension may also be tested by the extent to which it has exploited its existing route structure. If the same New York-Chicago carrier has been operating an extension to Des Moines which it has not exploited fully, it would appear difficult to conclude that the same carrier was "willing" to give the character of service to Milwaukee which is required by the "present and future needs of the foreign and domestic commerce," to quote Section 2 of the Act. In this sense the carrier may not be fully exploiting its principal New York-Chicago route, in which case it could hardly be "willing" to operate a Milwaukee extension. The present air map is full of route extensions which are not being fully exploited by certain carriers, but because mail subsidy is determined on the basis of over-all need there is little incentive for either the surrender or exploitation of such segments. ${ }^{77}$ Whether a carrier is "able" to operate a given extension would appear to be a matter of financing and engineering. If the extension to Milwaukee will increase the carrier's dependence upon mail subsidy, a serious question of "ability" arises. Likewise if planes, ground crews, and pilots are insufficient, if Milwaukee cannot handle larger planes or more flights without a new airport, if the extension will mean poor scheduling at important points, then there are questions of ability present.

Even if a carrier is "willing and able" to operate an extension, it may not be the "fit" carrier. Whether a carrier is "fit" should basically depend upon whether the extension requested is consistent with the comprehensive plan for the development of both the particular carrier and the entire industry. The proper application of this standard of the Act would appear to require the Board to engage in comprehensive planning for the industry. Significantly enough, Section 2 of the Act, which sets forth the declaration of policy, in two places specifically calls for the development of an air transportation system which will meet future as well as present needs.

The legislative standards "honest, economical and efficient management" are not placed haphazardly in the Act, but are set forth in Section 406(b) as conditions upon which mail subsidy may be provided the carriers. In effect they are limitations

\footnotetext{
${ }^{77}$ However, in a petition filed in 1948 , Northeast Airlines requested that a portion of its Route 27 be transferred to another carricr. See CAB Docket No. 3337 .
} 
upon the Board's power to dispense subsidy, but it is extremely difficult to show more than a mild influence of these standards upon the work of the Board. The same is true of the further condition upon the Board's authority to award subsidy, namely, that such subsidies be related to the continuance of "the development of air transportation to the extent and of the character and quality required. . . ." It is this sentence of Section 406(b) which so clearly links the payment of mail subsidies to the sections dealing with the declaration of policy and certificates of public convenience and necessity; it is both of these sentences which point up the concept of subsidy for use in fashioning a comprehensive air transportation system.

The Board has never concluded that subsidy should be denied because of the absence of "honest ... management." "78 Apparently the application of this standard has not gone far beyond insisting that carriers do not take candy from babies. When the Board tells the industry that freight rates must go higher and they immediately come down, is not a serious question of "honest management" involved? When the Board directs the filing of contract cargo rates in the midst of a rate war, and these are not filed for two years, is there no problem of "honest . . . management?" When a carrier cuts freight rates below those of a nonmail competitor immediately after receiving a large mail subsidy, should this be considered as an act of "honest management?" What about including items in the uniform accounts which do not belong there? What about making available to its officers stock options immediately after negotiating, but before making public announcement of, a substantial subsidy award? What about defying the United States Government in time of war?

Unquestionably the Board and its staff deserve credit for the attempt to require better utilization of equipment through the use of the "efficient management" standard. ${ }^{79}$ Here, however, instead of developing norms for measuring "efficient management," the Board simply has assumed that the average carrier has "efficient management" and makes no disallowance in mail subsidy cases unless utilization is substantially below the average. The Board has developed no administrative standards to implement the "economical management" standard of the Act, but simply lumps this legislative standard along with the "efficiency" standard as if the two standards were synonymous. ${ }^{80}$ It would appear that administrative standards

78 “... . Actually I do not know of any instance in which the specific finding of disallowance was based upon dishonesty.

"I was merely paraphrasing the statute which has the three words in it. Actually the disallowances with which I am familiar have been, in our judgment, examples of inefficient and uncconomical operations, and I do not recall any in which there has been an issue of dishonesty." 'Testimony of Chairman O'Connell in Hearings before Committee on Interstate and Foreign Conmerce on $S$. Res. 50, 8rst Cong., Ist Sess. 139 (1949).

${ }^{70}$ The Board's approach to efficiency is described in Sweency, note 36 stpra, at 152-154.

${ }^{80}$ E.g., see the Board opinions in the current "Big Four" mail rate case referred to in note is supra; see also testimony of Chairman O'Connell, note 77 supra; O'Connell, note 39 supra; Sweency, note 36 stipra at 152-154. It is not unusual that these two words should be regarded as synonymous. In a recent review of the report of the Hoover Commission, David Cushman Coyle offers this interesting criticism:

"Probably the chief fault of the commission's report is that it has accepted without clear definition the words 'economy and efficiency,' used in the enabling act practically as synonyms. In this context, 
supplementing the "economical management" statutory standard might be concerned with whether the carrier's economic planning is consistent with its own plan of development and with the over-all planning job carried out by the Board. It will be recalled that Section 2 is concerned with an air transportation system adapted to meet future as well as present needs. It is encouraging that at least Chairman O'Connell has recognized that "economical management" has a meaning quite distinct from that of "efficient management," Board decisions recognizing the distinction and its possibilities.

The writer has no brief for any particular administrative standards, or for that matter, for any specific use of the other techniques of planning; the foregoing are merely suggestive. It does seem clear, however, that only by the wisest and maximum use of these tools will the Board be able to formulate a comprehensive master plan for the regulation and development of both cargo and other traffic that can gain the respect of all concerned.

\section{III}

\section{Law and Planning}

It may be remarked that the foregoing suggestions will remake the Civil Aeronautics Board into another Atomic Energy Commission, Tennessee Valley Authority, or Department of Agriculture. It may be argued that as remade into a planning arm of the government the CAB will be forced to abandon the case-by-case approach of the Interstate Commerce Commission, which was given to it by the historical accident that aviation is a form of transportation which was once under the wing of the ICC. Lest there be any misunderstanding, that is exactly what is proposed. The growth character of air transportation requires planning rather than umpiring, and if the $C A B$ does not do the planning in the national interest the group supposedly being regulated will do the planning in their own interest. In fact, much of the history of aviation regulation under the Civil Aeronautics Act is no more than this latter story.

Planning does not require conflict with any concepts of fair hearing, such as those embodied in the Administrative Procedure $\mathrm{Act}^{82}$ and the Civil Aeronautics Act. ${ }^{83}$ It requires only that procedural forms will not be used to obstruct substantive decisions. The history of the OPA protest procedure ${ }^{84}$ and the procedure of the

economy properly means not buying what you don't need, while efficiency means getting the most for your money. That is, the words should refer on the one hand to policy, which is for Congress to decide, and on the other to management, which is the President's job as administrator." N. Y. Times Book Review, June $5,1949, \$ 7$, p. 27 , col. 2.

${ }^{81}$ O'Connell, note 39 supra.

${ }^{B 2} 60$ STAT. 237,5 U. S. C. $\$ \S 1001$ et seq. (1946).

s2 STAT. 977 (1938), 49 U. S. C. $\$ \$ 401$ et seq. (1946).

84 Unfortunately the history of the OPA protest procedure authorized by Section 203 of the Emergency Price Control Act (56 STAT. 23 (1942), 50 U. S. C. $\$ \$ 90$ I et seq. (1946)), has never been recorded. Some of it is reflected in Nathanson, The Emergency Court of Appeals, in Problems in Price Control: Legal Phases (Historical Reports on War administration, Gen. Pub. No. II, 1947), and in Hyman and Nathanson, Judicial Review of Price Control: The Battle of the Meat Regulations, 42 InI. L. Rev. 584 (1947). 
Department of Agriculture in administering the Agricultural Marketing Agreement $\mathrm{Act}^{85}$ suggest the feasibility of postponing hearings on individual cases until after the regulation or plan has been promulgated. ${ }^{80}$ Section 100r of the Civil Aeronautics Act fully authorizes a procedure that will meet the special needs of the agency's problem: "The Authority may conduct its proceedings in such manner as will be conducive to the proper dispatch of business and to the ends of justice."

Perhaps some comment is appropriate with respect to the place of administrative standards as formulated by the $\mathrm{CAB}$ in the legal framework. Do they mean nothing in an individual case, or do they replace the standards of the Act? These questions may both be answered in the negative. In an individual case, administrative standards may be attacked as being inconsistent with legislative standards, just as an act of Congress is frequently attacked as being inconsistent with our highest legal standard, the Constitution. The initial legal question upon judicial review would appear to be whether the administrative standards are consistent with the Act. If so, the remaining legal question would be whether the particular $C A B$ action-whether it be the master plan itself or a minor route decision-was consistent with the administrative standards. ${ }^{87}$ Of course, once the agency relies on such standards it is doubtful whether the courts would let it willy-nilly disregard them; instead they would become rules of the game by which all parties would abide. $^{88}$ It is this which makes them so important.

Such administrative standards and whatever comprehensive planning which flows therefrom need not be static. In working out standards in a growth industry such as aviation, two things must be kept in mind. In the first place, standards must anticipate changes in the development of the industry. Secondly, standards must be dovetailed with statistical controls so that if conditions change radically, standards can be changed as well. In addition, it must be borne in mind that experience with administering comprehensive regulations may require modification of administrative standards, thereby necessitating revision of the master plan, and in turn policy reversals on the part of the Board. However, it must be possible to explain these reversals in terms of these changes. In this context, a decision by the Board in a particular case in 1949 may be quite arbitrary and capricious as being inconsistent with the master plan or with the agency's administrative standards, yet ten years later be in perfect accord with the revised approach of the agency.

To the narrow legalist, such a procedure may appear at odds with the concepts of Anglo-American jurisprudence. True enough, our early history found case law, with its dependence upon the precedent of past decision, entirely adequate for a simple and stable society. But following the Industrial Revolution and subsequent

85 50 STAT. 246 (1937), 7 U. S. C. $\$ 608$ c (15)(A) (1946).

so The opinions of the Department of Agriculture's Judicial Officer are published monthly in Agr1cuiture Decistons. These opinions are among the most significant rendered in the field of Government regulation.

${ }^{87}$ Cf. Gillespie-Rogers-Pyatt Co. v. Bowles, 144 F. $2 d$ 36I (E. C. A. 1944); Armour \& Co. v. Bowles, 148 F. 2 d 529 (E. C. A. 1945).

${ }^{88}$ Cf. Armour \& Co. v. Brown, 137 F. $2 d 233$ (E. C. A. 1943); Hillerest Terrace Corp. v. Brown, 137 F. 2 d 663 (E. C. A. 1943). 
economic dislocations our community lost its faith in the administration of law solely by older techniques, and demanded a system under which government itself would take certain responsibilities for the development and enforcement of law, formerly assumed to be entirely private in nature. In this setting the case-by-case approach was found to have some value, but in addition such materials as legislative history, statutory interpretation, and administrative rules and interpretations gained relevance. Long after these developments occurred they were recognized as a distinct phenomenon of our jurisprudence and labeled "administrative law."

In the last twenty years we have discovered that controlling our economic system is a very complex task. The feeling is growing that survival and plenty cannot be grasped by amelioratory efforts to patch things up after a crisis has occurred. We are now concerned about preventing a crisis, about a long-range view of our natural resources and security. Our fear of things which may happen has driven us to planning in large areas of our economy. In these areas, the "administrative process" has or should take on new meaning. ${ }^{89}$ Perhaps this new departure in our legal system would be better understood if it is said that we have gone beyond administrative law; that "planning law" has become an additional facet of our jurisprudence. If this is so, the tools and techniques of planning must be recognized as both useful and legally relevant to the particular task.

It is extremely important that the Civil Aeronautics Board succeed in its assigned task to promote, develop, and encourage an air transportation system adequate to future as well as present needs. The authority of the $\mathrm{CAB}$ over air transportation could hardly be more comprehensive. It is one of the few agencies of our government with real national control over a particular area of the economy, a control deemed necessary by the industry itself. ${ }^{90}$ In some ways this type of control has been this nation's alternative to nationalization of the industry; but this alternative as presently administered has been such a costly venture ${ }^{91}$ that who can honestly say that nationalization-even assuming the grossest inefficiencies-would not be cheaper? It is the thesis of this paper that further chaos, excessive public expenditures, and perhaps even nationalization are inevitable unless the $C A B$ can soon discard the judicial machinery which served society so well before the Industrial Revolution, but which is so unequal to the task of planning the future of air transportation.

${ }^{80}$ Cf. James M. Landis, The Admanistrative Process (1938); David F. Cavers and Associates, Problems in Price Control: Pricing Standards (r947); and Myres S. McDougal and David Haber, Property, Wealth, Land: Allocation, Planning and Development (I948).

${ }^{\circ 0}$ For example, see the testimony of the late Colonel Edgar S. Gorrell, one time President of the Air Transport Assciation of American, in Hearings bcfore Subcommittee of Committee on Interstate and Foreign Commerce on S. 2 and S. 1760, 75th Cong., Ist Sess. 498 (1937).

01 "The constantly increasing amounts of subsidy payments in the form of mail pay granted to some of our air carriers has become a matter of national concern. The Government has paid out some Ioo million dollars in mail pay for the year 1948, with additional sums yet to come, and mail pay during 1949 is likey to reach a total of 125 million dollars. This compares with a total of some 230 million dollars paid to all of the airlines for all of the years since the passage of the Civil Acronautics Act prior to 1948." Dissenting opinion of Member Jones in Air Freight Certificate Case, Docket 8ro, Order Serial No. E-3085, July 29, I949, p. 40 . S. J. Res. 92, introduced May 16, 1949, by Senator Johnson of Colorado, uses the figure r Io million dollars for the year 1948 . 
